\title{
COMMERCIALIZATION OF INNOVATIONS THROUGH INTERNATIONALIZATION: A SYSTEMATIC LITERATURE REVIEW
}

\author{
Klaudia BRACIO $^{1}$, Marek SZARUCKI ${ }^{(2)}$ \\ ${ }^{1,2}$ Department of Strategic Analysis, Faculty of Economics and International Relations, \\ Cracow University of Economics, 27 Rakowicka St., 31-510, Cracow, Poland \\ E-mails: ${ }^{1}$ klaudiabracio@gmail.com; ${ }^{2}$ szaruckm@uek.krakow.pl (corresponding author)
}

Received 27 June 2019; accepted 27 August 2019

\begin{abstract}
The main purpose of the article is to identify the state of knowledge between two multidimensional phenomena: commercialization of innovation and internationalization. In terms of research methods, a systematic literature review, based on the 91 publications located in reputable scientific databases (Scopus and Web of Science) between the years 2000-2017 and Rapid Automatic Keyword Extraction (RAKE), was applied. The main findings provide information on the concept of commercialization of innovations via internationalization, and specifically on different research perspectives and areas of analysis with division of the bibliometric data. The selection of the articles for further analysis is perceived as the main limitation of this study, as some papers may not have been included due to missing keywords or due to having been absent from the two selected databases. The article analyses theoretical research and empirical papers and enables identification of problems in the current research as well as identifying trends in the area of the studied phenomenon. The results on the topic of commercialization of innovation through internationalization have indicated that this issue is still in a premature phase but with an upward trend of research development.
\end{abstract}

Keywords: innovations, commercialization of innovation, internationalization, research trends, systematic literature review.

JEL Classification: O00, D83, B49, L17.

\section{Introduction}

Innovations are an inseparable factor of social and economic development that has accompanied humanity since the beginning of civilization (Godin 2008, Cassiman et al. 2010, Szopik-Depczyńska 2015). Over the past decade, a significant increase in expenditures on innovative activities and a growing interest in the subject of innovation can be observed since technological change and innovations are often perceived as an influential process opening up opportunities to benefit societies, as well as social welfare in general (Gries et al. 2017).

Particular attention is paid to the commercialization of innovations as they are a fundamental condition for the development of both micro and macroeconomic aspects in the context of their impact on the creation of competitive advantages and economic development. Moreover, commercialization of innovations is arguably the most important challenge faced by all companies. As Drucker et al. (1986) have observed, innovation is beyond science or technology; it is something that is able to create value through the process of commercialization (Ahmed 1998).

The topic of commercialization of innovations has obviously gained increased attention in the recent period, however, this studied phenomenon is still fragmented and divided by different fields of study and disciplines. As a consequence, it is necessary to explore, arrange and aggregate all heterogeneous theoretical and empirical findings. This article fills the scientific gap by presenting the results of the systematic literature review, as well as distinguishing past trends and pointing out future trends. Based on the articles indexed in Scopus and Web of Science databases, the essence of commercialization of innovation in the context of

Copyright (c) 2019 The Authors. Published by VGTU Press.

This is an Open Access article distributed under the terms of the Creative Commons Attribution License (http://creativecommons.org/licenses/by/4.0/), which permits unrestricted use, distribution, and reproduction in any medium, provided the original author and source are credited. 
internationalization is explored and presented according to various bibliometric criteria.

The structure of the paper is as follows: the second section provides the research methodology and ways of collecting the documents from the vast literature of the studied subject. The third section presents the results of the systematic literature analysis, classifying the documents by their type; theoretical approaches applied; main findings and areas of analysis with division to the selected bibliometric criteria (i.e. journals, citations, number of authors, geographical location or keywords co-occurrence networks). The last section discusses the obtained results and provides suggestions for further research in this area.

\section{Research methodology}

A systematic literature review is the method that explores and sorts publications in order to identify the essential attributes of the studied materials. Rousseau et al. (2008) have stressed that systematic reviews utilise an ordered collection of concepts, interpretive reflections and analysis of the whole body of evidence relating to a specific question, which in our research is to shed light on the patterns and specifics of commercialization of innovation in relation to internationalization. Moreover, the systematic literature review has special values in distinguishing the past trends and forecasting future models. According to the method applied, steps suggested by Aliaga-Isla and Ralph (2013) are followed. The advantage of this method is that it focuses on individual journal researches and chooses small samples or characteristics of cases according to the subject requirements and the interests of researchers.

The first step of the method includes a precise formulation of search criteria. We have only included the journals written in the English language in Business, Management and Accounting subject areas and published between 2000 and 2017 in order to eliminate possible bias caused by delays in publishing. Nevertheless, all results should be treated with some reservation.

In order to recognize the interest in the subject of commercialization of innovations and internationalization, we decided to search for articles from the Web of Science and Scopus databases. One of the first articles on the commercialization of innovations was written in 1995. From 1995 to 2017 , the above topic was covered by 2892 articles in the Scopus database and 2015 articles in the Web of Science database. Another remarkable outcome from the data analysis is that 14,304 articles in the Scopus database and 11,834 articles in Web of Science were written on internationalization. Most publications (12\% in relation to all years) on both internationalization and commercialization of innovations were issued in 2017. For this reason, 2017 was chosen in our literature review as the final date.
For the literature search in Web of Science and Scopus databases, we have applied a set of alternative keywords including such combinations as: "commercialization of innovations through internationalization", "commercialization of innovative products in foreign markets", "product innovation in context of internationalization", "commercialization of innovation to the global community" and "collaboration across countries through innovations". Initially, after applying three criteria: years - "2000-2017", type - "article" and language "English", 362 articles were found.

After applying the next criterion, which selected only articles written on the subject of Business, Management and Accounting, only 133 articles were left. After the exclusion of duplicates, only 103 articles remained (see Table 1).

The first searching process included the investigation of the abstracts, which rejected 5 articles. After that, the second searching process was implemented, of which the main purpose was a thorough analysis of the abstract, introduction and conclusion sections. After this searching process, 2 articles were dropped out as irrelevant for our study. What is more, 3 articles did not include commercialization of innovations, although it was mentioned in the abstract.

The most common example for exclusion was the language of publication, because in some cases only the abstract was written in English. Two papers were eliminated because those articles concerned the commercialization of innovation only on the local market. Therefore, the final sample used for our literature review consists of 91 papers published

Table 1. Combinations of keywords and results of literature search in Web of Science and Scopus databases (source: own study)

\begin{tabular}{|l|c|c|c|}
\hline \multicolumn{1}{|c|}{ Alternative keywords } & $\begin{array}{c}\text { Web of } \\
\text { Science }\end{array}$ & $\begin{array}{c}\text { Sco- } \\
\text { pus }\end{array}$ & $\begin{array}{c}\text { Duplicated } \\
\text { according } \\
\text { to keywords } \\
\text { combination }\end{array}$ \\
\hline $\begin{array}{l}\text { Commercialization of } \\
\text { innovations through } \\
\text { internationalization }\end{array}$ & 4 & 11 & 2 \\
\hline $\begin{array}{l}\text { Commercialization of inno- } \\
\text { vative products in foreign } \\
\text { markets }\end{array}$ & 2 & 3 & 1 \\
\hline $\begin{array}{l}\text { Product innovation in context } \\
\text { of internationalization }\end{array}$ & 31 & 25 & 13 \\
\hline $\begin{array}{l}\text { Commercialization of inno- } \\
\text { vation to the global commu- } \\
\text { nity }\end{array}$ & 5 & 11 & 4 \\
\hline $\begin{array}{l}\text { Collaboration across countries } \\
\text { through innovations }\end{array}$ & 8 & 33 & 5 \\
\hline Total result of literature search & & 103 \\
\hline
\end{tabular}

Note: The total amount is different from the sum of all search results minus duplicate values, because different keywords combinations and different databases often overlap results in databases. 
between 2000 and 2017. After a precise investigation of their content, the database in MS Excel has been created, comprising different types of papers, techniques, methods, objects of analysis and summary of findings. The summary of the results of literature review is presented in the next section.

Below, a study of number of publications and citations of the studied literature collection was conducted to identify the state of research and problematic gaps in the area of joint enterprise internationalization and the implementation of innovations. This type of study is a prelude to theoretical and practical research. It allows to systematize the knowledge already created by other scientists, to identify the needs (or already provided answers) that the current state of knowledge generates. Moreover, it leads to the identification of issues that require in-depth analysis or they have not been recognized at all. Preliminary research allows the risk of duplicating answers to be minimized, as well as to formulate, more precisely, research goals and questions, or hypotheses in subsequent works on a given problem.

The first stage is a comparative analysis of the number of publications, graphs and the number of citations, which leads to the evaluation of the development stage of the literature collection and the underlying issues and - along with the internal analysis of connections - its homogeneity. This allows for predicting an increase or decrease in interest in the issue, which reflects the objectivity of the subjective perception of the relevance of the problem for science - and is directly related to the importance of answering questions related to the research gaps identified in the given area.

The observed number of citations shows high randomness in relation to the number of publications (see Figure 1), even taking into account the publishing cycle and the resulting delays in the dissemination of articles. This is due to two phenomena: the first is the low homogeneity of the publications, expressed by a small number of citations (only

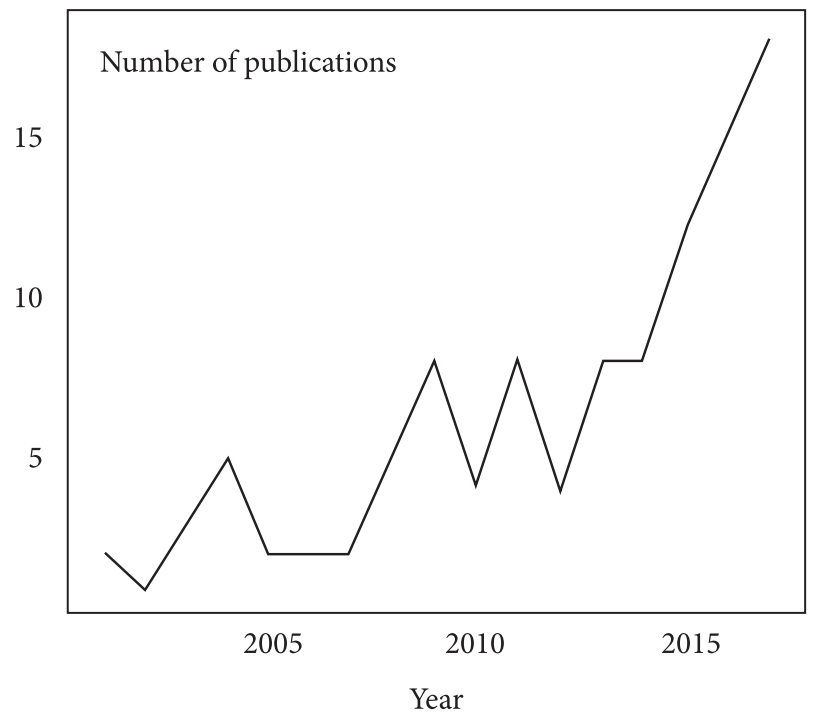

9 works $-8.7 \%$ - quote any other from the collection), which does not result from an unrelated bibliographic database, as it is 584 works ( $11.9 \%$ out of 4907 references); this is also manifested in the large number of journals in which articles are published. Only "Research Policy" has published 5 articles; they appear in stable time intervals (2004, 2008, $2009,2015,2017)$, which suggests that this is probably the most appropriate journal for targeting texts related to this issue. The next are "Technovation", "International Journal of Technology Management", "International Journal of Operations \& Production Management" and "International Entrepreneurship and Management Journal", each with 3 publications, where "Technovation" has (according to the average: 2012, 2015, 2016) the most recent articles of them all - is in an upward trend. The second reason is the small number of publications in general, which is noticeable in the form of significant fluctuations in the number of publications, which translates into the lack of recognition of the issue as such, but also the lack of specialization: only 9 out of 266 authors worked on two publications from the collection. This indicates the chances of specialization in the internationalization of innovations, where the authorship or co-authorship of at least 3 articles is a condition.

Compared with Lotka's schedule (Lotka 1926) in de Solla Price's interpretation (de Solla Price 1986), this is the number of publications below the elite borderline (i.e. 10 publications), especially since there is a theoretical capacity for the author who would be responsible for 14 publication (with $c=213$ in $=2$ for Lotka's distribution should be 1.087 author with 14 publications). It is also an argument demonstrating that, at the current moment, one cannot talk about this topic as a coherent part of knowledge.

The superficial examination of the content of the articles examined becomes an even more important aspect, especially in the absence of homogeneity. Due to the fact that

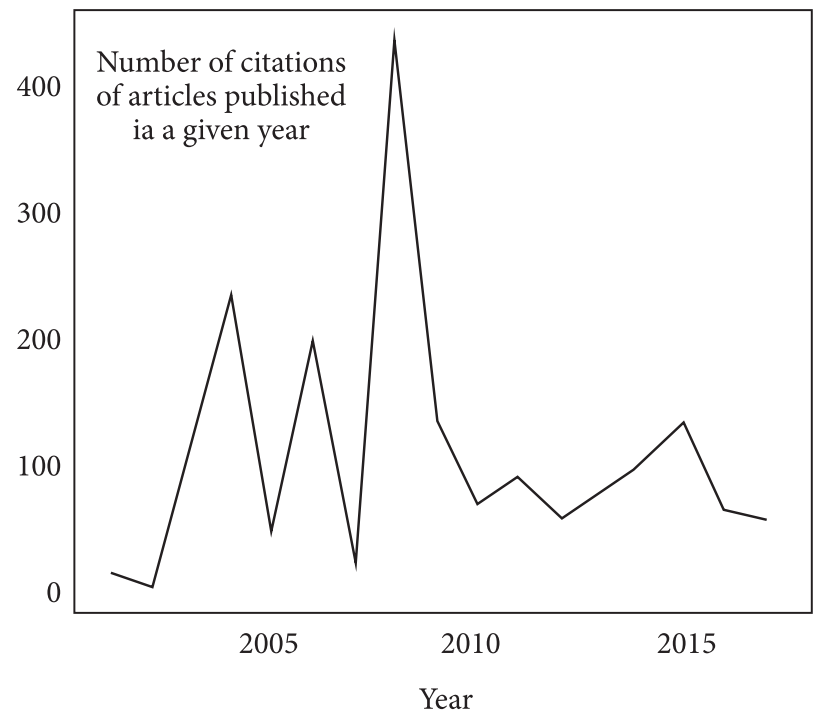

Figure 1. Number of publications and number of citations of the studied literature collection (source: own study) 


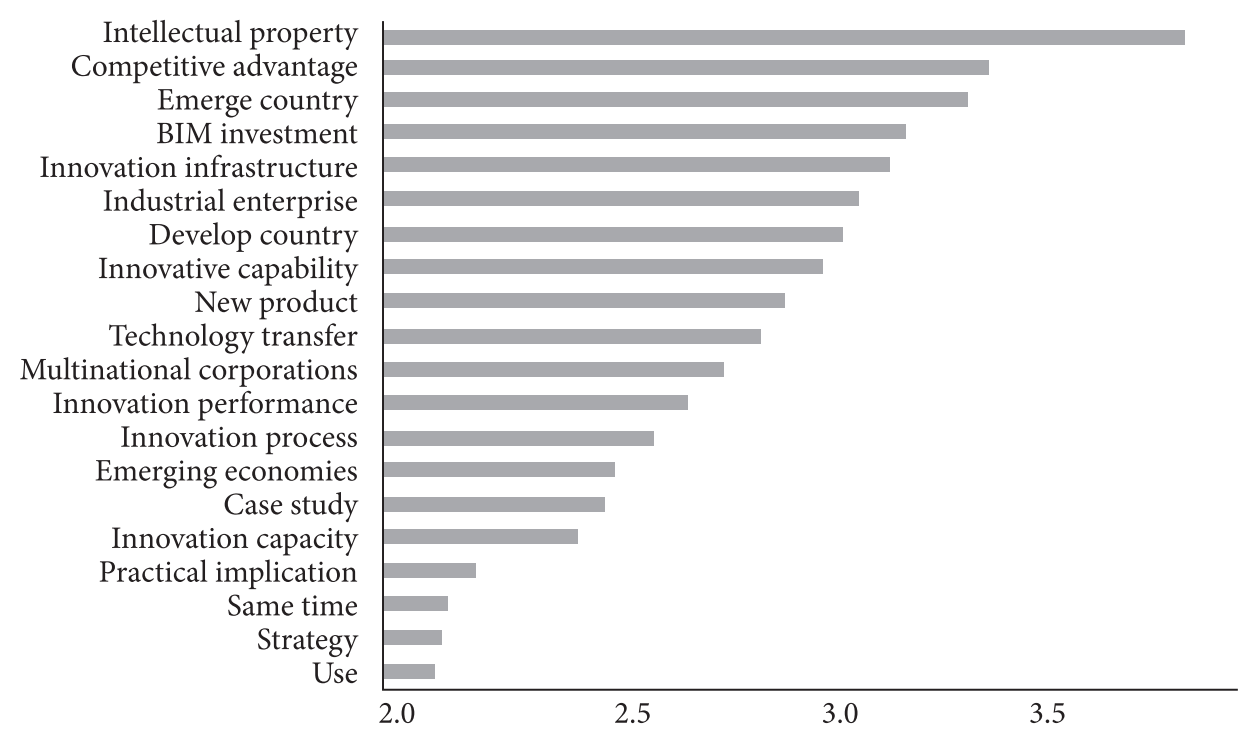

Figure 2. Identification of keywords by the RAKE method (source: own study)

abstracts were also searched, they were used to identify keywords by the RAKE method (Berry and Kogan 2010, pp. 6-9). The udpipe package (Wijffels 2018) for the language $\mathrm{R}(\mathrm{R}$ Core Team 2018) was used for this purpose, the method was carried out on lemmas (basic forms of expression), so as not to multiply variations of the same phrases.

The set of keywords identified from the abstracts is quite extensive (see Figure 2). Intellectual property shows the greatest link here, as well as in descending order, such terms as competitive advantage, emerging economies or developing countries.

Intellectual property, innovation infrastructure, industrial enterprises, innovative capacity, new products, technology transfer, multinational corporations - these are all concepts identified as essential for the commercialization of innovation through internationalization, whose relationship with the examined subject is sometimes not obvious. This is due to the poor structuring of the research area, which indicates the need for a systematic review of literature which, by exploiting threads, would indicate the developmental and the most important, from the examined perspective, but would merge them into a coherent whole.

After a summary review of the collection due to its separation, it is worth going to the properties of the publication related to their individual characteristics (number of authors, citations, etc.) and then to a cursory, geographical division of the threads into countries. Enterprises in different countries, having a completely different internal market, have - in detail - other motives for undertaking international cooperation (apart from increasing the sales market) and this is reflected in the affiliations of the authors.

\section{Results of literature review}

Many researchers around the world argue that amongst the most important factors shaping business success in recent decades are innovations and firms' internationalization (Buckler and Zien 2003, Szopik-Depczyńska et al. 2018, Wind and Mahajan 2006). A lot of evidence confirming the interdependence between innovation and internationalization has been consistently established in the literature on innovations. We can identify two examples of the connection amongst innovation and internationalization in which this process seems to be considered in the literature.

The first one, is the relationship between internationalization and innovation, in which the impact of innovation on the internationalization of an enterprise is assumed. This approach is based on the assumption that the internationalization of the company is the result of its earlier innovative activity. This means that innovation allows the company to internationalize (Cassiman et al. 2010, Cassiman et al. 2007). The second one is the relationship between innovation and internationalization, based on the reverse premise, in which the impact of internationalization on the innovativeness of the companies is assumed. Internationalization of the company increases its access to new knowledge and makes it necessary to meet new challenges, which, as a consequence, leads to an increase in its innovativeness. In this case, innovation is the result of internationalization (Bastian and Tucci 2017, Zahra et al. 2000).

The studies on commercialization of innovations are interdisciplinary, that is most easily observed in heterogeneous publication sources (see appendix 1). The 34 papers (37\% of the sample) included in our analysis have been published in journals specialising in technology and innovations. We have also identified 28 articles in the area of management and 21 papers in business and entrepreneurship journals. Another 4 papers were published in educational journals. Only two papers were found in marketing journals and two in regional periodicals.

Based on heterogeneous publication sources we can conclude that this field of research is divided into at least three 
different research areas in which the explored objects are placed (Archibugi and Michie 1995, Narula and Zanfei 2004):

- Profit-seeking (national and transnational) companies and individuals;

- Public research centres and universities, national and transnational companies;

- Transnational companies (TNCs).

For this reason, articles from the above literature review were published in journals in the area of small and medium-sized enterprises (SMEs), such as Small Business Economics, Human Resource Management Journal, International Marketing Review, academic journals (Oxford Development Studies, Cambridge Journal of Regions, Economy and Society) or those concerning R\&D in TNCs (e.g. Business Horizons, International Journal of Technology Management).

As a result, based on this data, three main categories of innovation internationalization can be distinguished. In the first category, TNCs and national enterprises as well as individuals are engaged in the international commercialization of technology developed at home. The second category relates to international and domestic scientific and technical collaborations amongst public and private institutions, including universities, TNCs, domestic firms and research centres. International innovation by TNCs is the third category. The TNC is the only institution that can carry out and control within its boundaries the process of innovation across the globe.

The description of our dataset, which presents information on the journal and authors out of 91 papers included in the analysis, show relatively large number of authors per paper (see Figure 3). Only 14 papers (almost 15\%) are created by solo authors. This is typically a common tendency in the global academic community, in which the position of scientific collaboration and research group is becoming progressively significant. The process of knowledge creation has fundamentally changed and this advantage has been increasing over time, because teams produce the exceptionally high-impact research (Wuchty et al. 2007). Therefore, 77 articles (over $84 \%$ ) are written by two or more authors. The

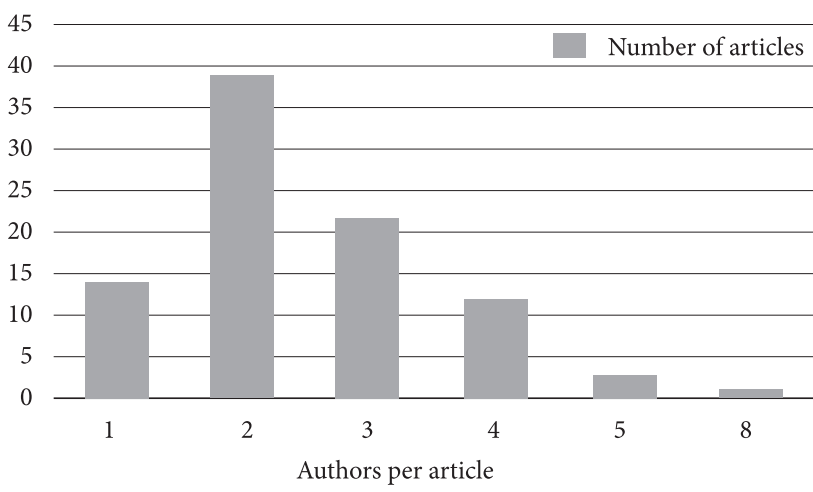

Figure 3. Number of authors per article (source: own study)

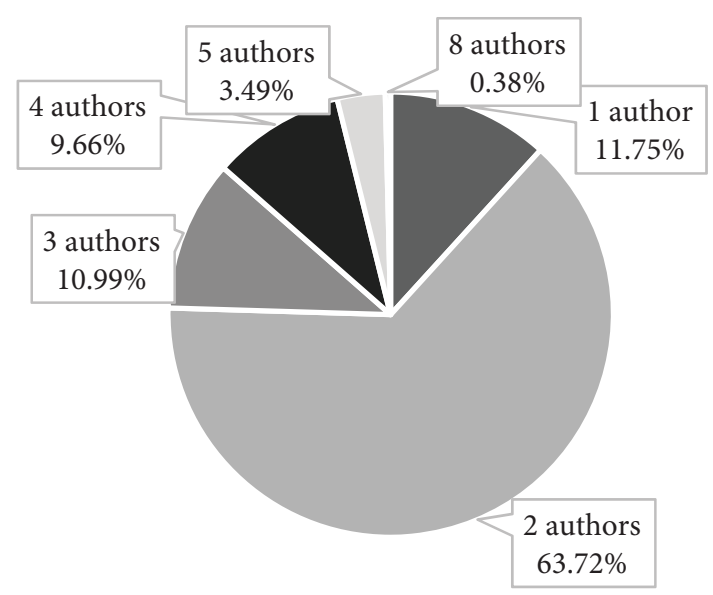

Figure 4. Times cited depending on the number of authors (source: own study)

number of articles authored by two people is sizable. Over $42 \%$ of the analysed papers have two authors.

A second highly relevant observation is a significant advantage in the number of citations (64\%) of the articles written by two authors (see Figure 4). This effect is not stronger if there are more co-authors per paper.

We have to indicate that research on the commercialization of innovation through internationalization is still at its early stage of development, as evidenced by the number of published articles on this subject, which is growing year by year. Most of the papers included in our analysis (79 of 91 papers, 87\%) have been published after 2007 (see Figure 5).

Some authors indicate that after the global financial crisis (2007-2008), most countries were affected by the accelerating pace of generating and transferring knowledge across national borders. There are only few papers, published before 2007. Increasing interest in this subject before 2007 was caused by the accession of many countries to the European Union, building a knowledge-based economy and the feasibility of the goal set by the European Council during the Lisbon summits (March 2000) and Barcelona (March 2002), that is, to increase European R\&D expenditure to 3 per cent of GDP by 2010 (Archibugi and Coco 2005). One of the earliest papers in our database is the study of Archibugi and Coco (2001).

Figure 6 presents the patterns of geographical coverage of the articles analysed in our study. Considering the fact that authors from the different countries cooperate with each other, in order to obtain unambiguous results, we applied the lead author's affiliation as a determinant for the articles being discussed. The majority of the studies included in our analysis have been conducted on the USA (Engel and del-Palacio 2009, DeFillippi 2015, Bagchi-Sen and Scully 2004, Sahaym et al. 2012, Cunningham and Link 2015, Pett and Wolff 2009, Hegde and Shapira 2007, Snow et al. 2011, Acworth 2008, Levina and Vaast 2008, Rodriguez et al. 2013, 


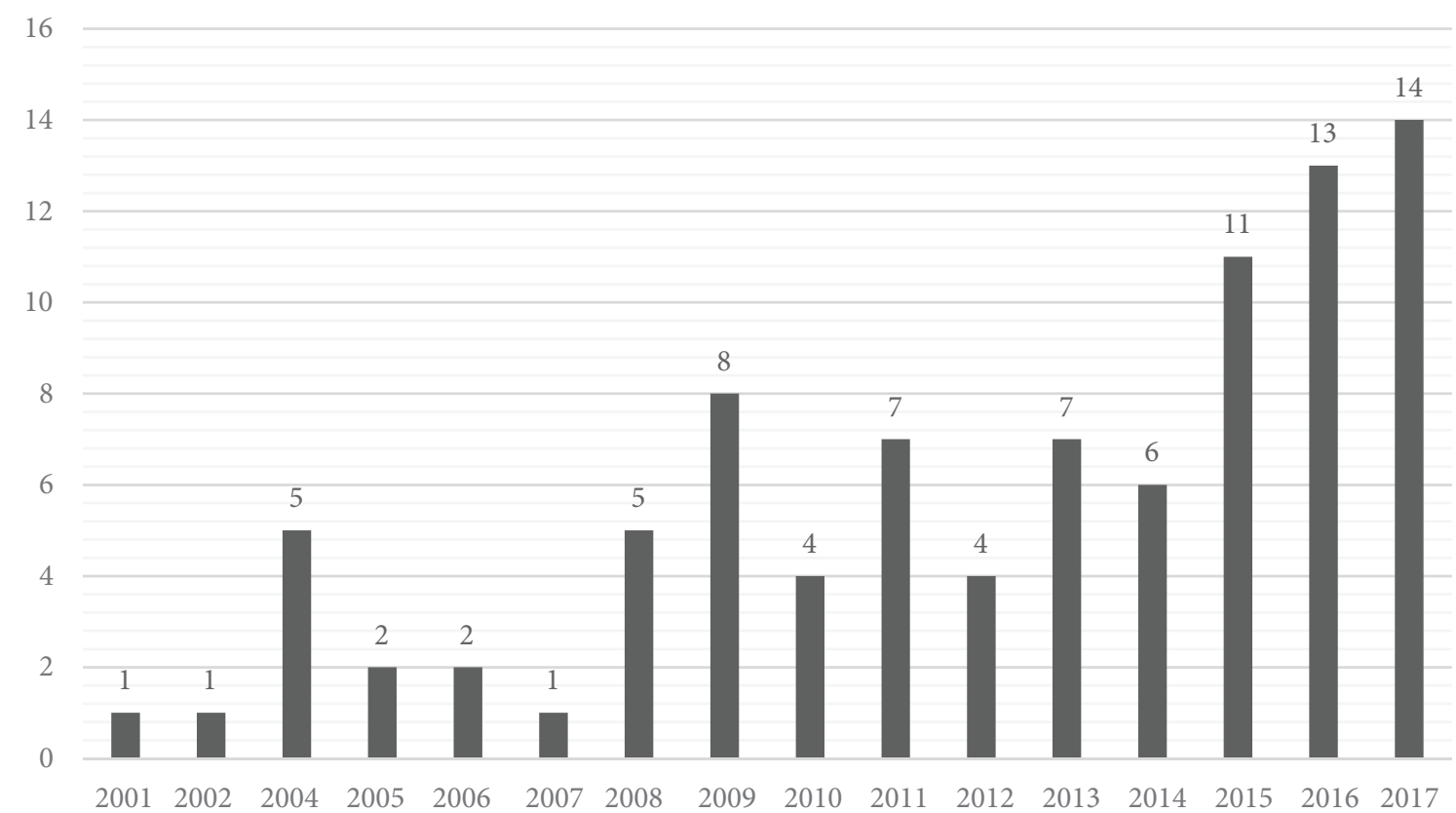

Figure 5. Number of articles indexed in Scopus and Web of Science after excluding duplicates by year of publication (source: own study)

Vasudeva 2009, Wu et al. 2016), followed by Italy (Archibugi and Coco 2001, Archibugi and Coco 2005, Cerrato and Piva 2015, Checchinato et al. 2017, Colombo et al. 2016, Dellera and Verganti 2009, Di Matteo et al. 2015, Fabrizi et al. 2016, Geisler and Turchetti 2015, Greco et al. 2016, Johnson and Filippini 2010). Paradoxically, a lot of articles on a given subject were written by the authors from Italy, although most of them do not describe the situation in this country, but refer to others, such as the USA, Japan, China and the whole of Europe. According to the European Innovation scoreboard (Hollanders and Es-Sadki 2018) the Western Europe countries tend to improve their position in innovation performance compared with the United States, Japan, Canada and China.

Additionally, 12 articles were written by the authors whose affiliation is the United Kingdom (Bezerra et al. 2015, Gadman and Cooper 2005, Islam and Ozcan 2013, Kafouros et al. 2015, Mabey and Zhao 2017, SATO 2014, Smith et al. 2008, Symeonidou et al. 2017, Lew et al. 2013, Miozzo and Dewick 2004, Ryan et al. 2010, Stokes et al. 2017). Traditionally for business studies, a lot of attention has been paid to China, South Korea and Taiwan (Prange and Bruyaka 2016, Rong et al. 2015, Sun and Liu 2014, Yu et al. 2011, Zhou et al. 2016, Ahn et al. 2017, Choi et al. 2012, Kohrt et al. 2016). Articles elaborated by the authors from Asia contain valuable information due to empirical justification.

Articles written by authors from the European countries are characterized by research on the particularly developed business sectors in the country where the given article is published. For example, articles whose country of author's affiliation is Norway concern the marine energy industry and education (Izunwanne 2011, Løvdal and Neumann 2011, Vaaland and Ishengoma 2016). Authors from Finland examine innovation support service requirements of Small Technology Firms (STFs) (Hätönen 2010, Pellikka and Virtanen 2009, Siikonen et al. 2011). In Sweden, issues related to the protection of intellectual property, cooperation of small companies with universities and case studies were explored (Andersson and Berggren 2016, Laurell et al. 2017, Pehrsson 2016, Stefan and Bengtsson 2017).

The most typical object of analysis in Denmark were case studies and challenges related to the high-tech global startups (Benito et al. 2013, Harirchi and Chaminade 2014). The papers from Belgium included case studies in international corporations and also in local companies functioning in the food industry (Kühne et al. 2013, Van den Waeyenberg and Hens 2012).

Finally, the only bibliometric literature review, applied by Stek and van Geenhuizen (2016) in the Netherlands, which is a good supplement to our literature review, included the impact of international research interactions on national innovation performance. The second paper from the Netherlands authored by Tijssen (2004) presents a review of corporate articles concerning the commercialization of scientific research.

From other European countries, e.g. Spain, four articles were written about commercialization of innovations in SMEs and in the craft products sector (Guzmán-Cuevas et al. 2009, Küster and Vila 2011, Molina et al. 2014, Rialp-Criado and Komochkova 2017). In addition, three articles from Greece have been written about innovation performance of young firms, acquisition of technologies by international 
corporations and on the development of transnational technology transfer (Fafaliou et al. 2010, Manolopoulos et al. 2009, Protogerou et al. 2017).

Unsurprisingly, a lot of studies from Germany still rely on protection of knowledge from those who seek to gain control of it through the acquisition of legal rights, such as intellectual property rights, as knowledge is becoming an essential resource in the global economy (Busingye and Keim 2009). In this context, fast and efficient adjustment to changing market conditions is one of the company core-competences for long lasting strengthening of market position (Lass et al. 2013).

In studies both from France and Croatia, considerable attention was paid to cooperation with universities. However, only two articles have been written on this topic (Dabic et al. 2016, Scaringella 2016).

In an article from Switzerland, the internationalization process and its reasons were described (Reiner et al. 2008). Similar topics were investigated in Serbia, where more attention was paid to the relationship between innovation and internationalization in Chinese companies (Zivlak et al. 2017).

Less often the attention has been paid to product market participation on indigenous innovation efforts (Chittoor et al. 2015). The authors from Nigeria and Portugal published two papers about the positive relationship between the network activities of companies and innovation (Egbetokun 2015, Franco and Haase 2015).

Australia is represented by Mort and Weerawardena (2006), where they explored the development of networking capability in Australian born global firms. Other authors offer a fresh and new perspective on empirical research on this topic describing the internationalization of innovative capabilities and adding new evidence to the debate on the

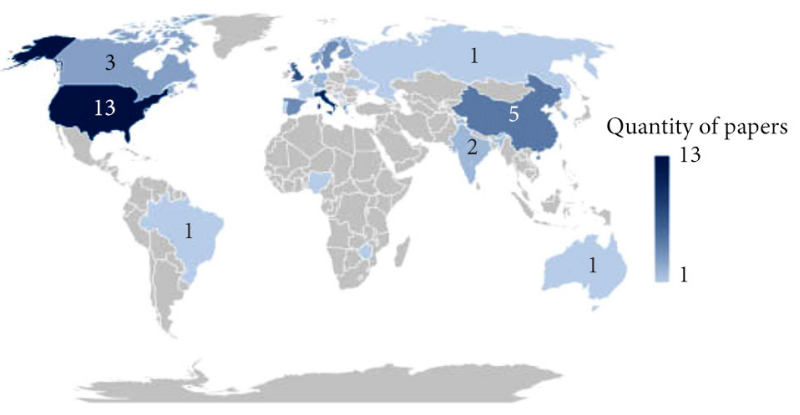

Figure 6. Coverage by geographical locations (source: own study)

internationalization of innovation in the industrial, technological, space, educational and service sectors (Ariffin and Figueiredo 2004, Bastian and Tucci 2017, Chebbi et al. 2017, Kabanda 2008, Kharbanda 2011, Krishna et al. 2012, Mothe and Mallory 2006, Pankova 2002, Raymond et al. 2014, Savchenko and Pustovoyt 2017).

Our study results have stressed that the research on commercialization of innovation through internationalization is still in the early stages of development, which is demonstrated by the relatively high dispersion of research.

Finally, the bibliographic data from Scopus in .ris extension was converted to .txt extension of plain-text format used by Web of Science with the CiteSpace converter utility (Chen 2006). Then, based on these two files, a keywords co-occurrence network was created and analysed with VOSviewer (van Eck and Waltman 2010). There were 766 unique keywords, 26 appeared at least 5 times, and this was chosen as a threshold for the research, to eliminate purely accidental and unrelated keywords. They formed 4 thematic clusters (see Figure 7).

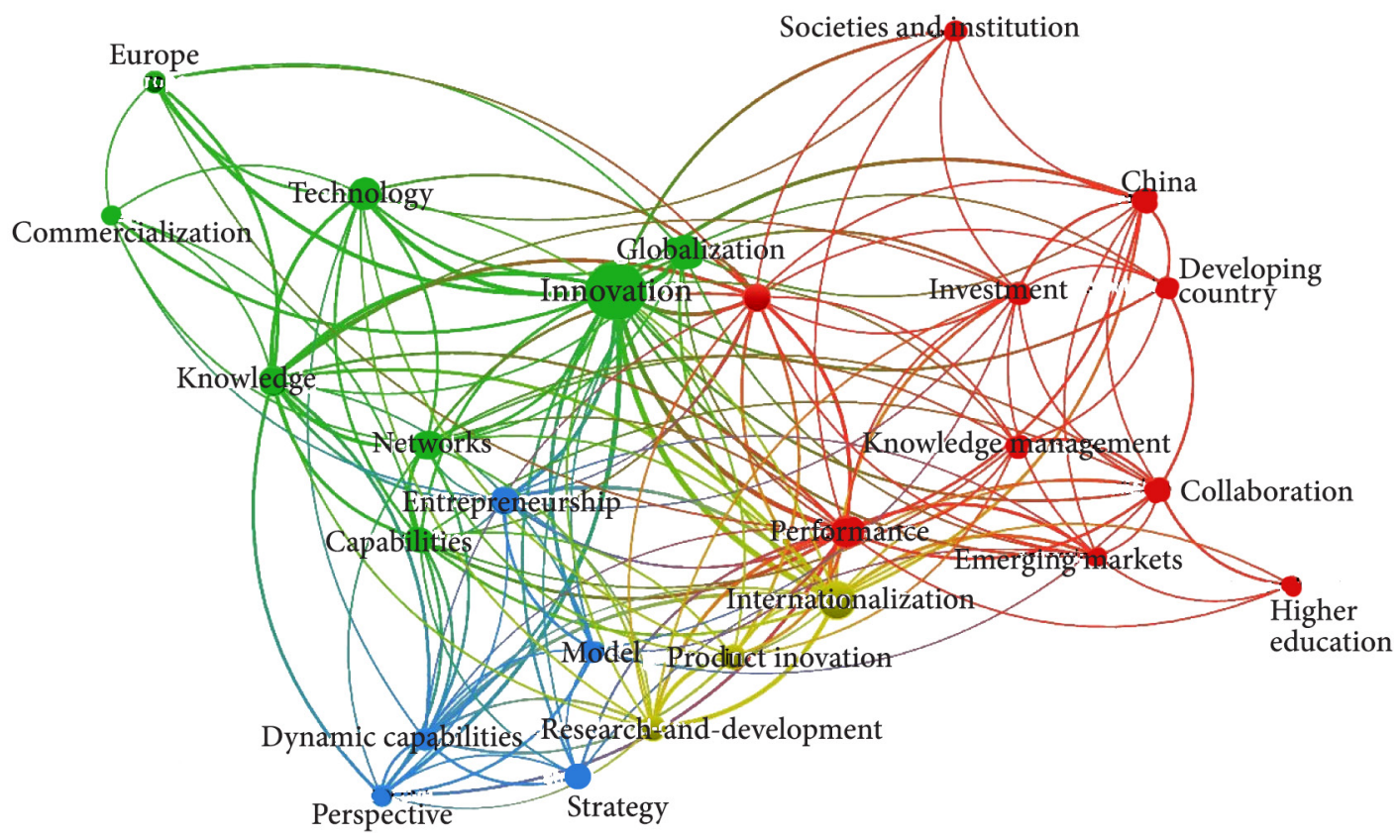

Figure 7. Keywords co-occurrence network with coloured clusters, node size by number of occurrences (source: own study) 
Modularity of thematic network means that, apart from the central concepts that are obvious given the query types (internationalization and innovation), there are other research areas highly related to the scope of the query, like product development, entrepreneurship and dynamic capabilities. This outcome brings two conclusions. Firstly, the division of interest should be noticed in the literature review. It means that these identified areas should be subjected to additional, deepened literature analysis leading to better categorisation of the related areas (clusters) of knowledge. Secondly, further analysis that would enhance understanding of this division's nature and explore social aspect of links is required to fully understand the leading authors and possible knowledge gaps.

\section{Conclusions}

Our paper is aimed at identifying the state of knowledge on commercialization of innovations through internationalization, based on a systematic literature review. The present results indicate that, in each article, the influence of commercialization of innovations on internationalization has been presented in a different way. However, each paper confirms and shows a positive relationship between innovation and international development. Owning innovative resources and abilities leads to the growth of the company both in domestic and foreign contexts. Among immaterial resources, innovations and technological resources play a fundamental role. The company's growth depends on the combined impact of innovation and internationalization. In addition, according to the perception adopted in innovative models, internationalization is perceived as an innovation and thus the development of innovation opens market opportunities. Our results enrich the existing research and complement the only bibliometric literature review conducted by Stek and van Geenhuizen (2016) related to the investigated subject.

Based on the applied methodology (RAKE, Lotka's schedule) we concluded that our systematic literature review was important to conduct it. Initial research proved that there is poor structuring of the research area and the need to explore threads based on the identified set of keywords from abstracts. The comparison of the number of citations in relation to the number of publications shows that there is rapid growth of articles compared with the slower growth of the number of citations. This is due to two phenomena: the first is the low homogeneity of the publications and the second is significant fluctuations in number of citations, which translates into the lack of recognition and lack of specialization.

The first highly relevant conclusion that can be drawn based on our database is that most of the authors tend to publish articles in teams of 2 or 3 co-authors. This is a common tendency in a global academic community, in which the position of scientific collaboration and research group is becoming progressively significant. Additionally, the most cited papers are those written by two authors and the growth of citations is not correlated with an increase in the number of co-authors. The second conclusion that can be observed is the growing, year by year, of the number of publications on this subject. It allows the conclusion that commercialization of innovation through internationalization is still in its early stage of development with growing tendency for further research.

Most of the analysed papers were written by authors from the USA, Japan, China and Western Europe. This confirms the practical patterns of the developed business sectors with strong emphasis on innovations creation and their commercialization very often internationally (Hollanders and Es-Sadki 2018). Finally, we explored the keywords co-occurrence network and identified four thematic clusters. The first, and biggest, is innovation, then in descending order are: internationalization, performance and entrepreneurship and the last one by importance.

Our study suggests that there are many unexplored topics because this strand of research is still in its early phase of development. The most obvious appropriate candidates for further investigations are the papers, which would include the, until now, missing geographical locations, i.e. smaller European countries that have joined the European Union. This would be particularly interesting from the perspective of showing mutual benefits for a country sharing and adopting innovations.

A limitation of this study to mention is the selection of the articles, since some papers may have not been included due to the missing keywords or that the articles have not been included in the search in the two chosen databases. What is more, there is a clear need for reconsidering the approach toward the research on the moment the idea is created, until it is implemented as an innovation. It might be interesting from a scientific point of view, as most commercialization of scientific research is often fulfilled by entrepreneurs cooperating with an academic world or by companies set up by scientists in order to make profits from the conducted research. In this aspect, it would be particularly interesting to perform a more in-depth analysis of successful projects and to determine the amount of profits achieved through their implementation.

\section{Funding}

This work was supported by the Polish National Agency for Academic Exchange under Grant No. PPN/ BEK/2018/1/00429/U/00001 and the funds allocated to the Faculty of Economics and International Relations of the Cracow University of Economics in the framework of grants for maintaining research potential. 


\section{Author contributions}

We have equally contributed to the work.

\section{Disclosure statement}

We have no conflict related to any competing financial, professional, or personal interests from other parties.

\section{References}

Acworth EB (2008) University-industry engagement: The formation of the Knowledge Integration Community (KIC) model at the Cambridge-MIT Institute. Research Policy 37 (8): 1241-1254. https://doi.org/10.1016/j.respol.2008.04.022

Ahmed P (1998) Benchmarking innovation best practice. Benchmarking for Quality Management \& Technology 5 (1): 45-58. https://doi.org/10.1108/14635779810206803

Ahn JM, Kim DB, Moon S (2017) Determinants of innovation collaboration selection: a comparative analysis of Korea and Germany. Innovation: Management, Policy and Practice 1 (2): 125-145. https://doi.org/10.1080/14479338.2016.1241152

Aliaga-Isla R, Rialp A (2013) Systematic review of immigrant entrepreneurship literature: previous findings and ways forward. Entrepreneurship \& Regional Development 25 (910): 819-844. https://doi.org/10.1080/08985626.2013.845694

Andersson S, Berggren E (2016) Born global or local? Factors influencing the internationalization of university spin-offs the case of Halmstad University. Journal of International Entrepreneurship 14 (3): 296-322. https://doi.org/10.1007/s10843-016-0182-z

Archibugi D, Coco A (2001) The technological performance of europe in a global setting. Industry and innovation 8 (3): 245 266. https://doi.Org/10.1080/13662710120104574

Archibugi D, Coco A (2005) Is Europe becoming the most dynamic knowledge economy in the world? JCMS: Journal of Common Market Studies 43 (3): 433-459. https://doi.org/10.1111/j.0021-9886.2005.00564.x

Archibugi D, Michie J (1995) The globalisation of technology: a new taxonomy. Cambridge Journal of Economics 19 (1): 121-140. https://doi.org/10.1093/oxfordjournals.cje.a035299

Ariffin N, Figueiredo PN (2004) Internationalization of innovative capabilities: counter-evidence from the electronics industry in Malaysia and Brazil. Oxford Development Studies 32 (4): 559-583. https://doi.org/10.1080/1360081042000293344

Bagchi-Sen S, Scully JL (2004) The Canadian environment for innovation and business development in the biotechnology industry: a firm-level analysis. European Planning Studies 12 (7): 961-983. https://doi.org/10.1080/0965431042000267867

Baraldi E, Ingemansson HM (2016) Identifying new dimensions of business incubation: A multi-level analysis of Karolinska Institute's incubation system. Technovation 50: 53-68. https://doi.org/10.1016/j.technovation.2015.08.003

Bastian BL, Tucci CL (2017) Entrepreneurial advice sources and their antecedents. Journal of Enterprising Communities: People and Places in the Global Economy 11 (2): 214-236. https://doi.org/10.1108/JEC-03-2015-0023

Benito GRG, Dovgan O, Petersen B, Welch LS (2013) Offshore outsourcing: A dynamic, operation mode perspective. Industrial Marketing Management 42 (2): 211-222. https://doi.org/10.1016/j.indmarman.2012.08.003
Berry MW, Kogan J (2010) Text mining: applications and theory. UK, West Sussex: John Wiley and Sons, 1-20. https://doi.org/10.1002/9780470689646

Bezerra MA, Borini FM, Maclennan MLF (2015) Reverse transfers of innovation and national development: Evidence from Brazilian subsidiaries. Journal of Technology Management and Innovation 10 (4): 1-8.

https://doi.org/10.4067/S0718-27242015000400001

Bitzer V, Bijman J (2014) Old Oranges in New Boxes? Strategic partnerships between emerging farmers and agribusinesses in South Africa. Journal of Southern African Studies 40 (1): 167-183. https://doi.org/10.1080/03057070.2014.877647

Buckler SA, Zien KA (2003) The spirituality of innovation: learning from stories. Journal of Product Innovation Management 13 (5): 391-405. https://doi.org/10.1111/1540-5885.1350391

Busingye J, Keim W (2009) The political battlefield: negotiating space to protect indigenous and traditional knowledge under capitalism. International Social Science Journal 60 (195): 37 54. https://doi.org/10.1111/j.1468-2451.2009.01699.x

Cassiman B, Golovko E, Martínez-Ros E (2010) Innovation, exports and productivity 28 (4): $372-376 \mathrm{https}: / / \mathrm{pdfs} . s e m a n$ ticscholar.org/ac4c/b6cffaa02e5b5c8a7ce879330e7f7df6d 532. pdf

Cassiman B, School B, Leuven KU, Martínez-Ros E (2007) Product innovation and exports evidence from Spanish manufacturing. IESE Business School Working Papers, 1-32 http://www.eco.uc3m.es/temp/agenda/Cassiman.pdf

Cerrato D, Piva M (2015) The effect of global orientation on the performance of international new ventures: evidence from Italy. Management International Review 55 (6): 857-883. https://doi.org/10.1007/s11575-015-0255-6

Chebbi H, Yahiaoui D, Thrassou A (2017) Multi-country collaborative innovation in the internationalisation process. International Marketing Review 34 (1): 109-137. https://doi.org/10.1108/IMR-12-2015-0286

Checchinato F, Hu L, Perri A, Vescovi T (2017) Leveraging domestic and foreign learning to develop marketing capabilities. International Journal of Emerging Markets 12 (3): 637-655. https://doi.org/10.1108/IJoEM-04-2015-0060

Chen C (2006) CiteSpace II: Detecting and visualizing emerging trends and transient patterns in scientific literature. Journal of the American Society for Information Science and Technology 57 (3): 359-377. https://doi.org/10.1002/asi.20317

Chittoor R, Aulakh PS, Ray S (2015) Accumulative and assimilative learning, institutional infrastructure, and innovation orientation of developing economy firms. Global Strategy Journal 5 (2): 133-153. https://doi.org/10.1002/gsj.1093

Choi DG, Lee Y, Jung M, Lee H (2012) National characteristics and competitiveness in MOT research: A comparative analysis of ten specialty journals, 2000-2009. Technovation 32 (1): 9-18. https://doi.org/10.1016/j.technovation.2011.09.004

Colombo MG, Piva E, Quas A, Rossi-Lamastra C (2016) How high-tech entrepreneurial ventures cope with the global crisis: changes in product innovation and internationalization strategies. Industry and Innovation 23 (7): 647-671. https://doi.org/10.1080/13662716.2016.1196438

Cunningham JA, Link AN (2015) Fostering university-industry R\&D collaborations in European Union countries. International Entrepreneurship and Management Journal 11 (4): 849-860. https://doi.org/10.1007/s11365-014-0317-4 
Dabic M, Vlajcic D, Novak I (2016) Entrepreneurial management education needs in the Republic of Croatia, Poland and the United Kingdom. International Journal of Educational Management 30 (6): 738-755.

https://doi.org/10.1108/IJEM-08-2014-0111

DeFillippi R (2015) The different perspectives on international strategy. In Developing strategic business models and competitive advantage in the digital sector. Hershey, PA: IGI Global, 85-123. https://doi.org/10.4018/978-1-4666-6513-2.ch004

Dellera C, Verganti R (2009) The impact of international designers on firm innovation capability and consumer interest. International Journal of Operations \& Production Management 29 (9): 870-893. https://doi.org/10.1108/01443570910986201

Derek J de Solla Price (1986) Little science, big science.. and beyond. Columbia University Press, 73-75 http://www.garfield. library.upenn.edu/essays/v10p072y1987.pdf?fbclid=IwAR05_ ZdVO4_Z6W_6BabP9nnsf28zCeCegOV4HLozAzXTzzfwEv aXSQQAOpg

Di Matteo G, Nardi P, Ceci P, Bajocco S, Perini L, HerreroCorral G, Gabiña D, Mugnozza GS (2015) Linking the forest research in the Mediterranean area: A framework to improve research capacities and cooperation. Forest Policy and Economics 50: 292-301. https://doi.org/10.1016/j.forpol.2014.08.003

Drucker PF, Talley T, Dutton EP, York N (1986) Management tasks, responsibilities, practices http://www.icmbpl.com/ Management - Tasks, Responsibilities, Practices by Peter Drucker e book.pdf

Egbetokun AA (2015) The more the merrier? Network portfolio size and innovation performance in Nigerian firms. Technovation, 43-44, 17-28. https://doi.org/10.1016/j.technovation.2015.05.004

Engel JS, del-Palacio I (2009) Global networks of clusters of innovation: Accelerating the innovation process. Business Horizons 52 (5): 493-503. https://doi.org/10.1016/j.bushor.2009.06.001

Fabrizi A, Guarini G, Meliciani V (2016) Public knowledge partnerships in European research projects and knowledge creation across R\&D institutional sectors. Technology Analysis \& Strategic Management 28 (9): 1056-1072. https://doi.org/10.1080/09537325.2016.1181741

Fafaliou I, Melanitis NE, Tsakalos V (2010) Commercialising research results in immature technology transfer markets: cases from the Greek experience. International Journal of Entrepreneurship and Innovation Management 11 (2): 213. https://doi.org/10.1504/IJEIM.2010.030069

Franco M, Haase H (2015) Internationalization of small technology-based firms: the role of strategic alliances. Strategic Alliances for SME Development (SASD). University of New York, 157-174.

Gadman S, Cooper C (2005) Strategies for collaborating in an interdependent impermanent world. Leadership \& Organization Development Journal 26 (1): 23-34. https://doi.org/10.1108/01437730510575561

Geisler E, Turchetti G (2015) Commercialization of technological innovations: the effects of internal entrepreneurs and managerial and cultural factors on public-private inter-organizational cooperation. International Journal of Innovation and Technology Management 12 (02): 1-26. https://doi.org/10.1142/S0219877015500091
Godin B (2008) Innovation: the history of a category www.csiic.ca

Gries T, Grundmann R, Palnau I, Redlin M (2017) Innovations, growth and participation in advanced economies-a review of major concepts and findings. International Economics and Economic Policy 14 (2): 293-351.

https://doi.org/10.1007/s10368-016-0371-1

Greco M, Grimaldi M, Cricelli L (2016) An analysis of the open innovation effect on firm performance. European Management Journal 34 (5): 501-516.

https://doi.org/10.1016/j.emj.2016.02.008

Guzmán-Cuevas J, Cáceres-Carrasco R, Soriano DR (2009) Functional dependence and productive dependence of SMEs. Small Business Economics 32 (3): 317-330. https://doi.org/10.1007/s11187-008-9115-0

Harirchi G, Chaminade C (2014) Exploring the relation between the degree of novelty of innovations and user-producer interaction across different income regions. World Development 57: 19-31. https://doi.org/10.1016/j.worlddev.2013.11.013

Hätönen J (2010) Outsourcing and licensing strategies in small software firms: evolution of strategies and implications for firm growth, internationalisation and innovation. Technology Analysis \& Strategic Management 22 (5): 609-630. https://doi.org/10.1080/09537325.2010.488066

Hegde D, Shapira P (2007) Knowledge, technology trajectories, and innovation in a developing country context: evidence from a survey of Malaysian firms. International Journal of Technology Management 40 (4): 349-370. https://doi.org/10.1504/IJTM.2007.015757

Hollanders H, Es-Sadki N (2018) European Innovation Scoreboard 2018. European Commission, Brussels http://ec.europa. eu/growth/industry/innovation/facts-figures/scoreboards_en

Islam N, Ozcan S (2013) Nanotechnology innovation system: an empirical analysis of the emerging actors and collaborative networks. IEEE Transactions on Engineering Management 60 (4): 687-703. https://doi.org/10.1109/TEM.2013.2265352

Izunwanne P (2011) Knowledge creation in multinational corporations: The role of organizational structure. Proceedings of the 12th European Conference on Knowledge Management 1 (1): 453-460.

Johnson WHA, Filippini R (2010) Collaboration practices, strategic capabilities and performance in Japanese and American product development: Do they differ? Operations Management Research 3 (1-2): 22-32. https://doi.org/10.1007/s12063-009-0025-3

Kabanda G (2008) Collaborative opportunities for ICTs development in a challenged African environment. Journal of Technology Management and Innovation 3 (3): 91-99. https://doi.org/10.4067/S0718-27242008000100009

Kafouros M, Wang C, Piperopoulos P, Zhang M (2015) Academic collaborations and firm innovation performance in China: The role of region-specific institutions. Research Policy 44 (3): 803-817. https://doi.org/10.1016/j.respol.2014.11.002

Kharbanda VP (2011) Academician to entrepreneur: Impact of globalization on science and technology policies in China and India. Journal of Science and Technology Policy in China 2 (1): 7-26. https://doi.org/10.1108/17585521111107870

Kohrt BA, Marienfeld CB, Panter-Brick C, Tsai AC, Wainberg ML (2016) Global mental health: five areas for value-driven training innovation. Academic Psychiatry 40 (4): 650-658. https://doi.org/10.1007/s40596-016-0504-4 
Krishna VV, Patra SK, Bhattacharya S (2012) Internationalisation of R\&D and Global Nature of Innovation: Emerging Trends in India. Science Technology \& Society 17 (2): 165-199. https://doi.org/10.1177/097172181101700201

Kühne B, Gellynck X, Weaver RD (2013) The influence of relationship quality on the innovation capacity in traditional food chains. Supply Chain Management: An International Journal 18 (1): 52-65. https://doi.org/10.1108/13598541311293177

Küster I, Vila N (2011) The market orientation-innovationsuccess relationship: Role of internationalization strategy. Innovation: Management, Policy and Practice 13 (1): 36-54. https://doi.org/10.5172/impp.2011.13.1.36

Lass S, Theuer H, Hennig G, Schumacher J (2013) Modellierung intelligenter Produktionssysteme. Productivity Management 18 (1): 47-50. https://doi.org/10.1145/359146.359152

Laurell H, Achtenhagen L, Andersson S (2017) The changing role of network ties and critical capabilities in an international new venture's early development. International Entrepreneurship and Management Journal 13 (1): 113-140. https://doi.org/10.1007/s11365-016-0398-3

Levina N, Vaast E (2008) Innovating or doing as told? Status differences and overlapping boundaries in offshore collaboration. MIS Quarterly 32 (2): 307-332. https://doi.org/10.2139/ssrn.1136880

Lew YK, Sinkovics RR, Kuivalainen O (2013) Upstream internationalization process: Roles of social capital in creating exploratory capability and market performance. International Business Review 22 (6): 1101-1120. https://doi.org/10.1016/j.ibusrev.2013.03.001

Lotka AJ (1926) The frequency distribution of scientific productivity. Journal of Washington Academy of Sciences 16 (12): 317-323.

Løvdal N, Neumann F (2011) Internationalization as a strategy to overcome industry barriers - an assessment of the marine energy industry. Energy Policy 39 (3): 1093-1100. https://doi.org/10.1016/j.enpol.2010.11.028

Rodriguez MCA, Wise J, \& Ruy Martinez C (2013) Strategic capabilities in exporting: an examination of the performance of Mexican firms. Management Decision 51 (8): 1643-1663. https://doi.org/10.1108/MD-10-2012-0766

Mabey C, Zhao S (2017) Managing five paradoxes of knowledge exchange in networked organizations: new priorities for HRM? Human Resource Management Journal 27 (1): 39-57. https://doi.org/10.1111/1748-8583.12106

Manolopoulos D, Dimitratos P, Young S, Lioukas S (2009) Technology sourcing and performance of foreign subsidiaries in Greece: The impact of MNE and local environmental contexts. Management International Review 49 (1): 43-60. https://doi.org/10.1007/s11575-008-0124-7

Miozzo M, Dewick P (2004) Networks and innovation in European construction: benefits from inter-organisational cooperation in a fragmented industry. International Journal of Technology Management 27 (1): 68. https://doi.org/10.1504/IJTM.2004.003882

Molina A, Aranda E, Martín VJ, Santos J (2014) Opportunities for craft consumption: analysis of the quality perceived by consumers. International Journal of Globalisation and Small Business 6 (1): 64-78. https://doi.org/10.1504/IJGSB.2014.063407
Mort GS, Weerawardena J (2006) Networking capability and international entrepreneurship: How networks function in Australian born global firms. International Marketing Review 23 (5): 549-572. https://doi.org/10.1108/02651330610703445

Mothe JD La, Mallory G (2006) Constructing Advantage: distributed innovation and the management of local economic growth. Prometheus 24 (1): 23-36. https://doi.org/10.1080/08109020600563812

Narula R, Duysters G (2004) Globalisation and trends in international R\&D alliances. Journal of International Management, Elsevier 10 (2): 199-218. https://doi.org/10.1016/j.intman.2004.02.007

Narula R, Zanfei A (2003) Globalisation of innovation the role of multinational enterprises. DRUID Working Papers 3 (15): 1-27 https://wp.druid.dk/wp/20030015.pdf

Pankova L (2002) Transfer of space technologies past and present: The Russian case. Journal of Technology Transfer 27 (4): 349360. https://doi.org/10.1023/A:1020263623811

Pehrsson A (2016) Sequential expansion in a foreign market. European Business Review 28 (3): 285-311. https://doi.org/10.1108/EBR-01-2016-0017

Pellikka J, Virtanen M (2009) Problems of commercialisation in small technology-based firms. International Journal of Entrepreneurship and Innovation Management 9 (3): 267-284. https://doi.org/10.1504/IJEIM.2009.025143

Pett TL, Wolff JA (2009) SME opportunity for growth or profit: what is the role of product and process improvement? International Journal of Entrepreneurial Venturing 1 (1): 5-21. https://doi.org/10.1504/IJEV.2009.023817

Prange C, Bruyaka O (2016) Better at home, abroad, or both? How Chinese firms use ambidextrous internationalization strategies to drive innovation. Cross Cultural \& Strategic Management 23 (2): 306-339. https://doi.org/10.1108/CCSM-07-2014-0079

Protogerou A, Caloghirou Y, Vonortas NS (2017) Determinants of young firms' innovative performance: Empirical evidence from Europe. Research Policy 46 (7): 1312-1326. https://doi.org/10.1016/j.respol.2017.05.011

R Core Team (2018) R: A language and environment for statistical computing. R Foundation for Statistical Computing, Vienna, Austria https://www.R-project.org/

Rasmussen ES, Petersen NH (2017) Platforms for Innovation and Internationalization. Technology Innovation Management Review 7 (5): 23-31. http://doi.org/10.22215/timreview/1074

Raymond L, St-Pierre J, Uwizeyemungu S, Le Dinh T (2014) Internationalization capabilities of SMEs: A comparative study of the manufacturing and industrial service sectors. Journal of International Entrepreneurship 12 (3): 230-253. https://doi.org/10.1007/s10843-014-0123-7

Reiner G, Demeter K, Poiger M, Jenei I (2008) The internationalization process in companies located at the borders of emerging and developed countries. International Journal of Operations \& Production Management 28 (10): 918-940. https://doi.org/10.1108/01443570810903096

Rialp-Criado A, Komochkova K (2017) Innovation strategy and export intensity of Chinese SMEs: the moderating role of the home-country business environment. Asian Business \& Management 16 (3): 158-186. https://doi.org/10.1057/s41291-017-0018-2 
Rong K, Wu J, Shi Y, Guo L (2015) Nurturing business ecosystems for growth in a foreign market: Incubating, identifying and integrating stakeholders. Journal of International Management 21 (4): 293-308. https://doi.org/10.1016/j.intman.2015.07.004

Rousseau DM, Manning J, Denyer D (2008) Evidence in management and organizational science: assembling the field's full weight of scientific knowledge through syntheses. The Academy of Management Annals 2 (1): 475-515. https://doi.org/10.1080/19416520802211651

Ryan A, Tilbury D, Blaze Corcoran P, Abe O, Nomura K (2010) Sustainability in higher education in the Asia-Pacific: developments, challenges, and prospects. International Journal of Sustainability in Higher Education 11 (2): 106-119. https://doi.org/10.1108/14676371011031838

Sahaym A, Treviño LJ, Steensma HK (2012) The influence of managerial discretion, innovation and uncertainty on export intensity: A real options perspective. International Business Review 21 (6): 1131-1147. https://doi.org/10.1016/j.ibusrev.2012.01.003

Sato CEY (2014) Platform leadership of incumbent telecommunications operators: The case of bt 21 st century network (bt $21 \mathrm{cn})$. International Journal of Innovation Management 18 (02): 1-37. https://doi.org/10.1142/S1363919614500157

Savchenko VF, Pustovoyt DV (2017) The analysis of innovation activity at industrial enterprises of Ukraine. Scientific Bulletin of Polissia 12 (10): 8-12.

https://doi.org/10.25140/2410-9576-2017-1-2(10)-8-12

Scaringella L (2016) Knowledge, knowledge dynamics, and innovation. European Journal of Innovation Management 19 (3): 337-361. https://doi.org/10.1108/EJIM-05-2015-0031

Siikonen J, Heimonen T, Pellikka J (2011) Developing innovation support services for small high-growth technology firms in Eastern Finland. International Journal of Entrepreneurial Venturing 3 (4): 392-419.

https://doi.org/10.1504/IJEV.2011.043385

Smith HL, Romeo S, Bagchi-Sen S (2008) Oxfordshire biomedical university spin-offs: an evolving system. Cambridge Journal of Regions, Economy and Society 1 (2): 303-319.

https://doi.org/10.1093/cjres/rsn010

Snow CC, Fjeldstad ØD, Lettl C, Miles RE (2011) Organizing continuous product development and commercialization: the collaborative community of firms model. Journal of Product Innovation Management 28 (1): 3-16. https://doi.org/10.1111/j.1540-5885.2010.00777.x

Stefan I, Bengtsson L (2017) Unravelling appropriability mechanisms and openness depth effects on firm performance across stages in the innovation process. Technological Forecasting and Social Change 120: 252-260.

https://doi.org/10.1016/j.techfore.2017.03.014

Stek PE, van Geenhuizen MS (2016) The influence of international research interaction on national innovation performance: A bibliometric approach. Technological Forecasting and Social Change 110: 61-70. https://doi.org/10.1016/j.techfore.2015.09.017

Stokes P, Moore N, Smith SM, Larson MJ, Brindley C (2017) Organizational ambidexterity and the emerging-to-advanced economy nexus: cases from private higher education operators in the United Kingdom. Thunderbird International Business Review 59 (3): 333-348. https://doi.org/10.1002/tie.21843
Sun Y, Liu F (2014) New trends in Chinese innovation policies since 2009 - a system framework of policy analysis. International Journal of Technology Management 65 (1/2/3/4): 6-23. https://doi.org/10.1504/IJTM.2014.060953

Symeonidou N, Bruneel J, Autio E (2017) Commercialization strategy and internationalization outcomes in technology-based new ventures. Journal of Business Venturing 32 (3): 302-317. https://doi.org/10.1016/j.jbusvent.2017.02.004

Szopik-Depczyńska K (2015) Effects of innovation activity in industrial enterprises in Eastern Poland. Oeconomia Copernicana 6 (2): 53-65. https://doi.org/10.12775/OeC.2015.012

Szopik-Depczyńska K, Cheba K, Kędzierska-Szczepaniak A, Szczepaniak K, Gajda W, Ioppolo G (2018) Innovation in sustainable development: an investigation of the EU context using 2030 Agenda indicators. Land Use Policy 79: 251-262. https://doi.org/10.1016/j.landusepol.2018.08.004

Tijssen RJ (2004) Is the commercialisation of scientific research affecting the production of public knowledge? Research Policy 33 (5): 709-733. https://doi.org/10.1016/j.respol.2003.11.002

Tsai Y (2013) Health care industry, customer orientation and organizational innovation. Chinese Management Studies 7 (2): 215-229. https://doi.org/10.1108/CMS-Oct-2011-0086

Vaaland TI, Ishengoma E (2016) University-industry linkages in developing countries: perceived effect on innovation. Education + Training 58 (9): 1014-1040. https://doi.org/10.1108/ET-07-2015-0067

Van den Waeyenberg S, Hens L (2012) Overcoming institutional distance: Expansion to base-of-the-pyramid markets. Journal of Business Research 65 (12): 1692-1699. https://doi.org/10.1016/j.jbusres.2012.02.010

Van Eck NJ, Waltman L (2010) How to normalize cooccurrence data? An analysis of some well-known similarity measures. Journal of the American Society for Information Science and Technology 60 (8): 1635-1651.

https://doi.org/10.1002/asi.21075

Vasudeva G (2009) How national institutions influence technology policies and firms' knowledge-building strategies: A study of fuel cell innovation across industrialized countries. Research Policy 38 (8): 1248-1259.

https://doi.org/10.1016/j.respol.2009.05.006

Wijffels J (2018) udpipe: Tokenization, Parts of Speech Tagging, Lemmatization and Dependency Parsing with the "UDPipe" “NLP” Toolkit. R package version 0.6.1. https://doi.org/10.18653/v1/K17-3009

Wind J, Mahajan V (2006) Editorial: issues and opportunities in new product development: an introduction to the special issue. Journal of Marketing Research 34 (1): 1-12. https://doi.org/10.2307/3152060

Wu J, Arora AS, Arora A (2016) Experience the "ambience”: Testing perceptions of ambient advertising innovations between the United States and Indian consumers. International Journal of Emerging Markets 11 (2): 148-174. https://doi.org/10.1108/IJoEM-11-2013-0204

Wuchty S, Jones BF, Uzzi B (2007) The increasing dominance of teams in production of knowledge. Science 316 (5827): 10361039. https://doi.org/10.1126/science.1136099

Yu J, Liu H, Soh PH (2011) Building collaboration networks for $3 \mathrm{G}$ system development, attempts from China. International 
Journal of Information Technology and Management 10 (2/3/4): 151-166. https://doi.org/10.1504/IJITM.2011.042585

Zahra SA, Ireland RD, Hitt MA (2000) International expansion by new venture firms: international diversity, mode of market entry, technological learning and performance. Academy of Management Journal 43 (5): 925-950.

https://doi.org/10.2307/1556420

Zhou Y, Lu L, Chang X (2016) Averting risk or embracing opportunity? Exploring the impact of ambidextrous capabilities on innovation of Chinese firms in internationalization. Cross Cultural \& Strategic Management 23 (4): 569-589.

https://doi.org/10.1108/CCSM-07-2014-0085
Zivlak N, Ljubičić M, Xu M, Demko-Rihter J, Lalić B (2017) Learning by internationalization: positive effects on innovation in Chinese companies. Tehnicki Vjesnik - Technical Gazette 24 (3): 53-759. https://doi.org/10.17559/TV-20170307103404

UNSPECIFIED (2000) Lisbon European Council 23-24 March 2000. Presidency conclusions http://www.europarl.europa.eu/ summits/lis1_en.htm

UNSPECIFIED (2002) Barcelona European Council 15-16 March 2002. Presidency conclusions http://aei.pitt.edu/id/ eprint $/ 43345$

\section{APPENDIX 1}

List of articles included for literature review by journal (source: own study)

\begin{tabular}{|c|c|c|c|}
\hline Journal & $\begin{array}{l}\text { Number } \\
\text { of articles }\end{array}$ & Authors & $\begin{array}{l}\text { Times } \\
\text { Cited }\end{array}$ \\
\hline $\begin{array}{l}\text { Asian Business \& } \\
\text { Management }\end{array}$ & 1 & $\begin{array}{l}\text { Rialp-Criado and } \\
\text { Komochkoya } \\
(2017)\end{array}$ & 2 \\
\hline Business Horizons & 1 & $\begin{array}{l}\text { Engel and del- } \\
\text { Palacio (2009) }\end{array}$ & 37 \\
\hline $\begin{array}{l}\text { Cambridge } \\
\text { Journal of Regions, } \\
\text { Economy and } \\
\text { Society }\end{array}$ & 1 & $\begin{array}{l}\text { Smith, Romeo and } \\
\text { Bagchi-Sen (2008) }\end{array}$ & 14 \\
\hline $\begin{array}{l}\text { Chinese Manage- } \\
\text { ment Studies }\end{array}$ & 1 & Tsai (2013) & 4 \\
\hline $\begin{array}{l}\text { Cross Cultural \& } \\
\text { Strategic Manage- } \\
\text { ment }\end{array}$ & 2 & $\begin{array}{l}\text { Zhou et al. (2016) } \\
\text { Prange and } \\
\text { Bruyaka (2016) }\end{array}$ & $\begin{array}{l}0 \\
2\end{array}$ \\
\hline $\begin{array}{l}\text { Developing Stra- } \\
\text { tegic Business } \\
\text { Models and Com- } \\
\text { petitive Advantage } \\
\text { in The Digital } \\
\text { Sector }\end{array}$ & 1 & DeFillippi $(2015)^{\star}$ & 0 \\
\hline $\begin{array}{l}\text { Education and } \\
\text { Training }\end{array}$ & 1 & $\begin{array}{l}\text { Vaaland and } \\
\text { Ishengoma (2016) }\end{array}$ & 4 \\
\hline Energy Policy & 1 & $\begin{array}{l}\text { Løvdal and } \\
\text { Neumann (2011) }\end{array}$ & 23 \\
\hline $\begin{array}{l}\text { European Business } \\
\text { Review }\end{array}$ & 1 & Pehrsson (2016) & 1 \\
\hline $\begin{array}{l}\text { European Journal } \\
\text { of Innovation } \\
\text { Management }\end{array}$ & 1 & Scaringella (2016) & 2 \\
\hline $\begin{array}{l}\text { European } \\
\text { Management } \\
\text { Journal } \\
\end{array}$ & 1 & Greco et al. (2016) & 20 \\
\hline $\begin{array}{l}\text { European Planning } \\
\text { Studies }\end{array}$ & 1 & $\begin{array}{l}\text { Bagchi-Sen and } \\
\text { Scully (2004) }\end{array}$ & 18 \\
\hline
\end{tabular}

\begin{tabular}{|c|c|c|c|}
\hline Journal & $\begin{array}{l}\text { Number } \\
\text { of articles }\end{array}$ & Authors & $\begin{array}{l}\text { Times } \\
\text { Cited }\end{array}$ \\
\hline $\begin{array}{l}\text { Forest Policy and } \\
\text { Economics }\end{array}$ & 1 & $\begin{array}{l}\text { Di Matteo et al. } \\
(2015)\end{array}$ & 6 \\
\hline $\begin{array}{l}\text { Global Strategy } \\
\text { Journal }\end{array}$ & 1 & $\begin{array}{l}\text { Chittoor et al. } \\
(2015)\end{array}$ & 11 \\
\hline $\begin{array}{l}\text { Human Resource } \\
\text { Management } \\
\text { Journal }\end{array}$ & 1 & $\begin{array}{l}\text { Mabey and Zhao } \\
(2017)\end{array}$ & 7 \\
\hline $\begin{array}{l}\text { IEEE Transactions } \\
\text { on Engineering } \\
\text { Management }\end{array}$ & 1 & $\begin{array}{l}\text { Islam and Ozcan } \\
\text { (2013) }\end{array}$ & 12 \\
\hline $\begin{array}{l}\text { Industrial Marke- } \\
\text { ting Management }\end{array}$ & 1 & Benito et al. (2013) & 12 \\
\hline $\begin{array}{l}\text { Industry and } \\
\text { Innovation }\end{array}$ & 2 & $\begin{array}{l}\text { Colombo et al. } \\
(2016) \\
\text { Archibugi and Coco } \\
(2001)\end{array}$ & $\begin{array}{l}1 \\
5\end{array}$ \\
\hline $\begin{array}{l}\text { Innovation: } \\
\text { Management, } \\
\text { Policy and Practice }\end{array}$ & 2 & $\begin{array}{l}\text { Ahn et al. (2017) } \\
\text { Küster and Vila } \\
(2011)\end{array}$ & $\begin{array}{l}1 \\
9\end{array}$ \\
\hline $\begin{array}{l}\text { International } \\
\text { Business Review }\end{array}$ & 2 & $\begin{array}{l}\text { Sahaym et al. (2012) } \\
\text { Lew et al. (2013) }\end{array}$ & $\begin{array}{l}10 \\
18 \\
\end{array}$ \\
\hline $\begin{array}{l}\text { International } \\
\text { Entrepreneurship } \\
\text { and Management } \\
\text { Journal }\end{array}$ & 2 & $\begin{array}{l}\text { Cunningham and } \\
\text { Link (2015), } \\
\text { Laurell et al. (2017) }\end{array}$ & $\begin{array}{c}34 \\
1\end{array}$ \\
\hline $\begin{array}{l}\text { International Jour- } \\
\text { nal of Educational } \\
\text { Management }\end{array}$ & 1 & Dabic et al. (2016) & 1 \\
\hline $\begin{array}{l}\text { International Jour- } \\
\text { nal of Emerging } \\
\text { Markets }\end{array}$ & 2 & $\begin{array}{l}\text { Wu et al. (2016), } \\
\text { Checchinato et al. } \\
(2017)\end{array}$ & $\begin{array}{l}1 \\
0\end{array}$ \\
\hline $\begin{array}{l}\text { International Jour- } \\
\text { nal of Entrepre- } \\
\text { neurial Venturing }\end{array}$ & 2 & $\begin{array}{l}\text { Siikonen et al. } \\
\text { (2011) } \\
\text { Pett and Wolff } \\
(2009)\end{array}$ & $\begin{array}{l}0 \\
8\end{array}$ \\
\hline
\end{tabular}




\begin{tabular}{|c|c|c|c|}
\hline Journal & \begin{tabular}{|c|} 
Number \\
of articles
\end{tabular} & Authors & $\begin{array}{l}\text { Times } \\
\text { Cited }\end{array}$ \\
\hline $\begin{array}{l}\text { International } \\
\text { Journal of Entre- } \\
\text { preneurship } \\
\text { And Innovation } \\
\text { Management }\end{array}$ & 2 & $\begin{array}{l}\text { Fafaliou et al. } \\
(2010) \\
\text { Pellikka and } \\
\text { Virtanen (2009) }\end{array}$ & $\begin{array}{l}1 \\
7\end{array}$ \\
\hline $\begin{array}{l}\text { International } \\
\text { Journal of } \\
\text { Globalisation and } \\
\text { Small Business }\end{array}$ & 1 & Molina et al. (2014) & 2 \\
\hline $\begin{array}{l}\text { International Jour- } \\
\text { nal of Information } \\
\text { Technology and } \\
\text { Management }\end{array}$ & 1 & Yu et al. (2011) & 0 \\
\hline $\begin{array}{l}\text { International Jour- } \\
\text { nal of Innovation } \\
\text { and Technology } \\
\text { Management }\end{array}$ & 1 & $\begin{array}{l}\text { Geisler and } \\
\text { Turchetti (2015) }\end{array}$ & 0 \\
\hline $\begin{array}{l}\text { International Jour- } \\
\text { nal of Innovation } \\
\text { Management }\end{array}$ & 1 & Sato (2014) & 4 \\
\hline $\begin{array}{l}\text { International Jour- } \\
\text { nal of Operations } \\
\text { \& Production } \\
\text { Management }\end{array}$ & 2 & $\begin{array}{l}\text { Dell'era and } \\
\text { Verganti (2009) } \\
\text { Reiner et al. (2008) }\end{array}$ & $\begin{array}{l}16 \\
15\end{array}$ \\
\hline $\begin{array}{l}\text { International Jour- } \\
\text { nal of Sustainability } \\
\text { an Higher } \\
\text { Education }\end{array}$ & 1 & Ryan et al. (2010) & 53 \\
\hline $\begin{array}{l}\text { International Jour- } \\
\text { nal of Technology } \\
\text { Management }\end{array}$ & 3 & $\begin{array}{l}\text { Hegde and Shapira } \\
(2007) \\
\text { Miozzo and Dewick } \\
(2004) \\
\text { Sun and Liu (2014) }\end{array}$ & $\begin{array}{l}21 \\
27 \\
5\end{array}$ \\
\hline $\begin{array}{l}\text { International } \\
\text { Marketing Review }\end{array}$ & 2 & $\begin{array}{l}\text { Chebbi et al. (2017) } \\
\text { Mort and } \\
\text { Weerawardena } \\
(2006) \\
\end{array}$ & $\begin{array}{c}1 \\
183\end{array}$ \\
\hline $\begin{array}{l}\text { International Social } \\
\text { Science Journal }\end{array}$ & 1 & $\begin{array}{l}\text { Busingye and Keim } \\
(2009)\end{array}$ & 8 \\
\hline $\begin{array}{l}\text { Journal of Business } \\
\text { Research }\end{array}$ & 1 & $\begin{array}{l}\text { Van den } \\
\text { Waeyenberg and } \\
\text { Hens (2012) }\end{array}$ & 18 \\
\hline $\begin{array}{l}\text { Journal of Business } \\
\text { Venturing }\end{array}$ & 1 & $\begin{array}{l}\text { Symeonidou et al. } \\
(2017)\end{array}$ & 6 \\
\hline $\begin{array}{l}\text { Journal of Common } \\
\text { Market Studies }\end{array}$ & 1 & $\begin{array}{l}\text { Archibugi and } \\
\text { Coco (2005) }\end{array}$ & 35 \\
\hline $\begin{array}{l}\text { Journal of Enter- } \\
\text { prising Com- } \\
\text { munities-People } \\
\text { and Places in the } \\
\text { Global Economy }\end{array}$ & 1 & $\begin{array}{l}\text { Bastian and Tucci } \\
(2017)\end{array}$ & 0 \\
\hline $\begin{array}{l}\text { Journal of } \\
\text { International } \\
\text { Entrepreneurship }\end{array}$ & 2 & $\begin{array}{l}\text { Andersson and } \\
\text { Berggren (2016), } \\
\text { Raymond et al. } \\
(2014)\end{array}$ & $\begin{array}{c}1 \\
12\end{array}$ \\
\hline
\end{tabular}

\begin{tabular}{|c|c|c|c|}
\hline Journal & $\begin{array}{l}\text { Number } \\
\text { of articles }\end{array}$ & Authors & $\begin{array}{l}\text { Times } \\
\text { Cited }\end{array}$ \\
\hline $\begin{array}{l}\text { Journal of } \\
\text { International } \\
\text { Management }\end{array}$ & 2 & $\begin{array}{l}\text { Narula and } \\
\text { Duysters (2004) } \\
\text { Rong et al. (2015) }\end{array}$ & $\begin{array}{l}48 \\
17 \\
\end{array}$ \\
\hline $\begin{array}{l}\text { Journal of Product } \\
\text { Innovation } \\
\text { Management }\end{array}$ & 1 & Snow et al. (2011) & 40 \\
\hline $\begin{array}{l}\text { Journal of Science } \\
\text { and Technology } \\
\text { Policy in China }\end{array}$ & 1 & Kharbanda (2011) & 3 \\
\hline $\begin{array}{l}\text { Journal of Southern } \\
\text { African Studies }\end{array}$ & 1 & $\begin{array}{l}\text { Bitzer and Bijman } \\
(2014)\end{array}$ & 5 \\
\hline $\begin{array}{l}\text { Journal of Tech- } \\
\text { nology Mana- } \\
\text { gement and } \\
\text { Innovation }\end{array}$ & 2 & $\begin{array}{l}\text { Kabanda (2008) } \\
\text { Bezerra et al. (2015) }\end{array}$ & $\begin{array}{l}9 \\
2\end{array}$ \\
\hline $\begin{array}{l}\text { Journal of Tech- } \\
\text { nology Transfer }\end{array}$ & 1 & Pankova (2002) & 5 \\
\hline $\begin{array}{l}\text { Leadership and } \\
\text { Organization } \\
\text { Development } \\
\text { Journal } \\
\end{array}$ & 1 & $\begin{array}{l}\text { Gadman and } \\
\text { Cooper }(2005)\end{array}$ & 15 \\
\hline $\begin{array}{l}\text { Management } \\
\text { Decision }\end{array}$ & 1 & \begin{tabular}{|l} 
Rodriguez et al. \\
$(2013)$
\end{tabular} & 6 \\
\hline $\begin{array}{l}\text { Management } \\
\text { International } \\
\text { Review }\end{array}$ & 2 & $\begin{array}{l}\text { Manolopoulos et al. } \\
(2009) \\
\text { Cerrato and Piva } \\
(2015)\end{array}$ & $\begin{array}{l}10 \\
5\end{array}$ \\
\hline $\begin{array}{l}\text { Mis Quarterly: } \\
\text { Management } \\
\text { Information } \\
\text { Systems }\end{array}$ & 1 & $\begin{array}{l}\text { Levina and Vaast } \\
(2008)\end{array}$ & 328 \\
\hline $\begin{array}{l}\text { Operations } \\
\text { Management } \\
\text { Research } \\
\end{array}$ & 1 & $\begin{array}{l}\text { Johnson and } \\
\text { Filippini (2010) }\end{array}$ & 8 \\
\hline $\begin{array}{l}\text { Oxford } \\
\text { Development } \\
\text { Studies }\end{array}$ & 1 & $\begin{array}{l}\text { Ariffin and } \\
\text { Figueiredo (2004) }\end{array}$ & 73 \\
\hline $\begin{array}{l}\text { Proceedings of } \\
\text { the European } \\
\text { Conference on } \\
\text { Knowledge Mana- } \\
\text { gement, ECKM }\end{array}$ & 1 & Izunwanne $(2011)^{*}$ & 0 \\
\hline $\begin{array}{l}\text { Productivity } \\
\text { Management }\end{array}$ & 1 & Lass et al. (2013) & 2 \\
\hline $\begin{array}{l}\text { Prometheus } \\
\text { (United Kingdom) }\end{array}$ & 1 & $\begin{array}{l}\text { De La Mothe and } \\
\text { Mallory (2006) }\end{array}$ & 8 \\
\hline Research Policy & 5 & $\begin{array}{l}\text { Kafouros et al. } \\
(2015) \\
\text { Protogerou et al. } \\
(2017) \\
\text { Vasudeva (2009) } \\
\text { Tijssen (2004) } \\
\text { Acworth (2008) }\end{array}$ & $\begin{array}{l}35 \\
8 \\
\\
19 \\
65 \\
62\end{array}$ \\
\hline
\end{tabular}




\begin{tabular}{|c|c|c|c|}
\hline Journal & $\begin{array}{c}\text { Number } \\
\text { of articles }\end{array}$ & Authors & $\begin{array}{l}\text { Times } \\
\text { Cited }\end{array}$ \\
\hline $\begin{array}{l}\text { Science Technology } \\
\text { and Society }\end{array}$ & 1 & $\begin{array}{l}\text { Krishna et al. } \\
(2012)\end{array}$ & 19 \\
\hline $\begin{array}{l}\text { Scientific Bulletin } \\
\text { of Polissia }\end{array}$ & 1 & $\begin{array}{l}\text { Savchenko and } \\
\text { Pustovoyt (2017) }\end{array}$ & 0 \\
\hline $\begin{array}{l}\text { Small Business } \\
\text { Economics }\end{array}$ & 1 & $\begin{array}{l}\text { Guzmán-Cuevas } \\
\text { et al. (2009) }\end{array}$ & 29 \\
\hline $\begin{array}{l}\text { Strategic Allian- } \\
\text { ces for SME } \\
\text { Development }\end{array}$ & 1 & $\begin{array}{l}\text { Franco and Haase } \\
(2015)^{*}\end{array}$ & 0 \\
\hline $\begin{array}{l}\text { Supply Chain } \\
\text { Management- } \\
\text { an International } \\
\text { Journal }\end{array}$ & 1 & Kühne et al. (2013) & 19 \\
\hline $\begin{array}{l}\text { Technological } \\
\text { Forecasting and } \\
\text { Social Change }\end{array}$ & 2 & $\begin{array}{l}\text { Stek and van } \\
\text { Geenhuizen } \\
\text { (2016), Stefan and } \\
\text { Bengtsson (2017) } \\
\end{array}$ & $\begin{array}{l}4 \\
8\end{array}$ \\
\hline $\begin{array}{l}\text { Technology } \\
\text { Analysis \& Strategic } \\
\text { Management }\end{array}$ & 1 & Hätönen (2010) & 4 \\
\hline $\begin{array}{l}\text { Technology } \\
\text { Analysis and } \\
\text { Strategic } \\
\text { Management }\end{array}$ & 1 & Fabrizi et al. (2016) & 5 \\
\hline $\begin{array}{l}\text { Technology } \\
\text { Innovation } \\
\text { Management } \\
\text { Review }\end{array}$ & 1 & $\begin{array}{l}\text { Rasmussen and } \\
\text { Petersen (2017) }\end{array}$ & 0 \\
\hline Technovation & 3 & $\begin{array}{l}\text { Baraldi et al. } \\
(2016) \\
\text { Choi et al. (2012) } \\
\text { Egbetokun (2015) }\end{array}$ & $\begin{array}{l}14 \\
6 \\
7\end{array}$ \\
\hline Tehnicki Vjesnik & 1 & Zivlak et al. (2017) & 0 \\
\hline $\begin{array}{l}\text { Thunderbird } \\
\text { International } \\
\text { Business Review }\end{array}$ & 1 & Stokes et al. (2017) & 2 \\
\hline $\begin{array}{l}\text { World } \\
\text { Development }\end{array}$ & 1 & $\begin{array}{l}\text { Harirchi and } \\
\text { Chaminade (2014) }\end{array}$ & 5 \\
\hline Total & 91 & & 1572 \\
\hline
\end{tabular}

* The publication appears in the database as an article and chapter/ conference proceeding as well. The publication was included to our article to maintain consistency with the Scopus and Web of Science databases. 